\title{
Community Participation in the Village Fund Program in Kemang Manis Village, Tebing Tinggi District, Empat Lawang Regency, South Sumatra
}

\author{
Hikmah Adila ${ }^{1}$, Alfitri ${ }^{1}$, Andy Alfatih $^{1 *}$ \\ ${ }^{1}$ Faculty of Social Science and Political Science, Universitas Sriwijaya \\ *Correspondence Author, Email: andy.alfatih20@gmail.com
}

\begin{abstract}
This study aimed to find out how community participation in the Village Fund program in Kemang Manis Village in the Four Lawang District in 2016 and the factors that supported and blocked community participation in the village fund program in Kemang Manis Village. The method used was qualitative so that the data obtained through interviews, observation and study of documentation and qualitative descriptive analysis techniques. The results showed that at the decision making stage, the participation of the Kemang Manis village community in the Village Fund Program in 2016 was still low because the data synchronization activities were not carried out, only the village elite community and workers as well as grant providers, were invited, attended, gave opinions, and approve the results of the meeting's decision. At the implementation stage (community participation) was quite good, it appeared in the crowded community who registered themselves as candidates for village infrastructure activities, following the work briefing and direction from the village government. At the time of implementation the community brought their own carpentry equipment, donated food and drinks, and received wages or daily work incentives, and participants of community empowerment activities received transport money. The stages of the utilization of benefits (benefits) the community felt the benefits of the results of village development. Roads could be passed by 4 -wheeled vehicles, making it easier to transport agricultural produce, residents began to build houses because roads were available and land values had also increased. The community had not yet been involved
\end{abstract}




\section{OAIIJSS Open Access Indonesta}

Jounad of soctal sciences

in the monitoring, supervision and evaluation stages, because in the planning stages of the Village RPJM and Village RKP documents the community involvement is still low. At the stage of implementation of village development the community was involved as an implementer, but the procurement and financial management and administration activities were carried out by the village government. There were no complaints from the public and information disclosure regarding the new Village Fund in the form of a Village Infrastructure development project board.

\section{Keywords: community participation, village fund program, south sumatra}

\section{Introduction}

In the publication of the Central Statistics Agency (BPS) entitled Initial Portraits of Sustainable Development Goals in Indonesia, there are about 70 percent of the total indicators measuring the Millennium Development Goals (MDGs) that have been successfully achieved by Indonesia. However, several indicators that measure targets in the health sector are still quite far from achievement and should receive special attention. The targets that have not yet been achieved include the national poverty rate, infant mortality, maternal mortality, prevalence of malnutrition, HIV and AIDS prevalence and several indicators related to the environment. Poverty is a global issue and a multidimensional problem (Akbar, 2015; Alhafid, 2015; Azhar, 2015).

Law Number 6 of 2014 Concerning Villages is one of the public policies stipulated by the government to give village authority to regulate and manage government affairs, the interests of local communities. according to the village's definition in general terms. The government budgeted village funds nationally in the National Budget every year for villages and their allocation in each village was calculated based on population, poverty rate, area and geographical difficulty level. However, these funds were not fully optimal, a number of studies show that the number of poor and very poor in rural areas was still quite large (Nugroho, 2011; Singarimbun, 1982; Usman, 2012; Bahrudin, 2015; Darmawi, 2014). 


\section{OAIIJSS Open Access Indonesta}

Jounad of soctal sciences

One district that still has poverty problems is the Empat Lawang district. Empat Lawang regency is an expansion of Lahat regency, South Sumatra Province. Empat Lawang regency as a new autonomous region formed under Law No. 1 of 2007 was included in the middle-down income areas until 2014. In the vulnerable period from 2007 to 2015, the administrative area of the Empat Lawang regency consisted of 10 districts, 9 subdistricts and 147 villages with an area of 2,256.44 Km2. In the last five years, the development of poverty indicators in the Empat Lawang experienced only a slight increase.

This is because the budget of the village fund of the Four Lawang Regency especially Kemang Manis Village had not been used optimally. This situation was happened because some factors. They were community involvement at the decision making stage was still low; community involvement in the implementation phase still met obstacles; program communication was not smooth. These factors encouraged to find out how community participation in the Village Fund program and what factors support and hinder community participation.

\section{Literature Review}

In general terms, the term participation is the participation of a person or group of community members in an activity. Bornby (1974) in Mardikantor and Soebiato (2015: 81) for example, defines participation as an action to "take part" i.e. an activity or statement to take part of an activity with the intention of obtaining benefits. Community participation is the involvement of community members in an area, to take part and contribute to an activity, in the process of planning, implementing, feeling the benefits of development and conducting monitoring and evaluation for the common good. In theory, especially according to Slamet (1985) in Mardikanto and Soebiato 2013: 91, states that the growth and development of community participation in development, is determined by 3 (three) main elements, namely: the opportunity given to the community to participate, the will of the community to participate, the ability of the community to participate (Alfitri, 2011; Hadi, 2013; Laksana, 2013; Mau, 2015; Putra, 2015; Sulistiawati, 2013; Wibowo, 2011). 
The theory of participation as a reference in this study is the theory of Cohen and Uphoff's (1980). The parameters of community participation in development are: involved in making decisions, involved in implementation, involved in the utilization of results; and involved in evaluation. The selection of theories used has considerations, namely: to find out how the process of community participation in the Village Fund program can be seen from the community's involvement in each stage of participation referring to Permendagri Number 114 of 2014 concerning Guidelines for Village Development; and related to the phenomenon of community participation in the background of existing problems.

\section{Methods}

Data analysis technique in this study was a qualitative descriptive analysis technique. The data analysis model were consisted of following process; data reduction stage, data display stage, and verification stage. Respondent of this research were informants consisted of people of Kemang Manis Village who had or had never been involved in the Village Fund program; and have enough time to be interviewed. This study used qualitative data types and quantitative data presented in the form of numbers, tables, diagrams / graphs, and figures. The data of this study were obtained from data collection techniques, namely in-depth interviews and observations.

\section{Result and Discussion}

\section{Community Participation in Decision Making}

Community participation in decision making is part of the village program planning process that utilizes the Village Fund Budget. The results of this study in table 1 show that community participation in the planning process was still low and not optimal. Not infrequently, village activity planning is very centralized in the interests of village leaders. 
Tabel 1.Community Participation in Decision Making

\begin{tabular}{|c|c|c|}
\hline Dimension & Indicators & Findings \\
\hline \multirow[t]{2}{*}{$\begin{array}{l}\text { Community participation } \\
\text { in decision making }\end{array}$} & As resources & $\begin{array}{l}\text { Community participation } \\
\text { in providing information } \\
\text { is still low. } \\
\text { In compiling planning } \\
\text { documents, administrative } \\
\text { data have not been aligned } \\
\text { with real conditions in the } \\
\text { community. } \\
\text { Most people have never } \\
\text { been asked about } \\
\text { population data, natural } \\
\text { resources, and } \\
\text { development resources. } \\
\text { The preparation of } \\
\text { planning documents still } \\
\text { relies on the Village Local } \\
\text { Assistance and is based on } \\
\text { decision instructions by } \\
\text { the village government }\end{array}$ \\
\hline & Meeting Invitation & $\begin{array}{l}\text { There is no written } \\
\text { invitation for consultation } \\
\text { to the community from the } \\
\text { village government; } \\
\text { Deliberation invitation is } \\
\text { conducted verbally, by } \\
\text { telephone and delivering it } \\
\text { directly to the house. }\end{array}$ \\
\hline
\end{tabular}




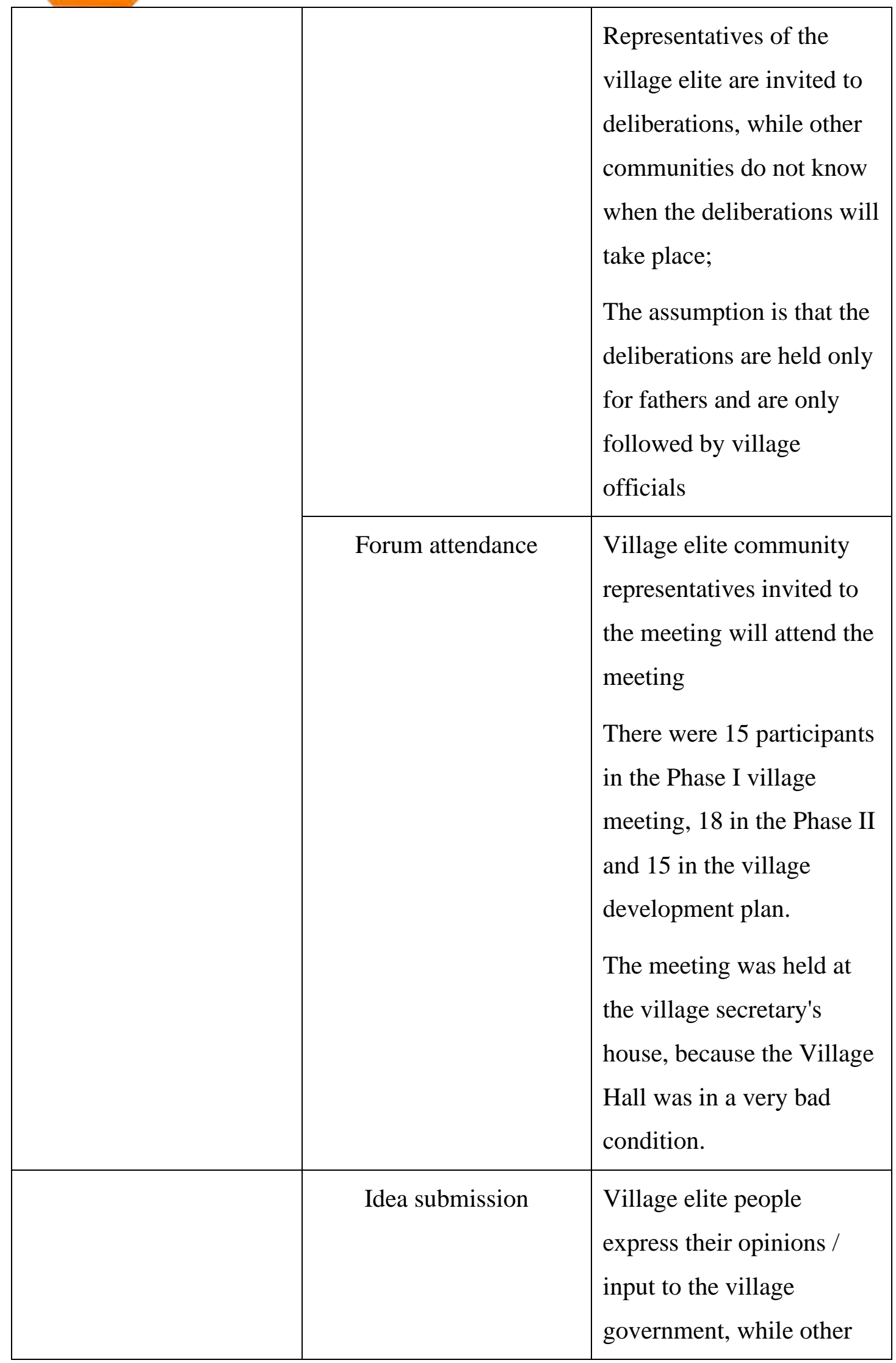




\begin{tabular}{|l|l|}
\hline & $\begin{array}{l}\text { community members do } \\
\text { not express their opinions; } \\
\text { The list of proposed } \\
\text { activities in the 2016 RKP } \\
\text { consists of 4 proposed } \\
\text { development activities, } \\
\text { and 16 proposed } \\
\text { empowerment activities; }\end{array}$ \\
\hline Deliberation agreement & $\begin{array}{l}\text { The village elite who } \\
\text { attended the meeting } \\
\text { agreed to the results of the } \\
\text { deliberations } \\
\text { In the Official Report that } \\
\text { approves and signs the } \\
\text { BPD, village government } \\
\text { and 1 community } \\
\text { representative. } \\
\text { Decision making is done } \\
\text { by determining the } \\
\text { priorities of several } \\
\text { proposals needed in } \\
\text { village 1 and village 2, and } \\
\text { development is carried out } \\
\text { in stages. }\end{array}$ \\
\hline
\end{tabular}

\section{Implementation}

Community participation in implementation is a form of community involvement in the preparation stage of work and field technical planning, participation in the form of personnel and participation in other empowerment activities. Village community participation in the village work program activities is quite good as shown in table 2. 
Table 2. Community participation in implementation

\begin{tabular}{|l|l|l|}
\hline Dimension & Indicator & Findings \\
\hline $\begin{array}{l}\text { Community participation } \\
\text { in implementation }\end{array}$ & Work preparation meeting & $\begin{array}{l}\text { Very good } \\
\text { People were enthusiast } \\
\text { because there were more } \\
\text { job vacancy }\end{array}$ \\
\hline & Activities implementation & $\begin{array}{l}\text { Very good, but it was still } \\
\text { low in community } \\
\text { empowerment activities } \\
\text { Because participants who } \\
\text { take part in various } \\
\text { activities are the same } \\
\text { person }\end{array}$ \\
\hline & People contribution & Very good and no obstacle \\
\hline
\end{tabular}

Participation in the utilization of results

Community participation from the beginning of planning, implementation to receiving benefits can foster a sense of ownership and preserve community members towards village development.

Table 3. Finding on utilization of results

\begin{tabular}{|l|l|l|}
\hline \multicolumn{1}{|c|}{ Dimension } & \multicolumn{1}{|c|}{ Indicator } & \multicolumn{1}{c|}{ Findings } \\
\hline $\begin{array}{l}\text { Community participation } \\
\text { in Product Utilization / } \\
\text { Benefit Receipt }\end{array}$ & $\begin{array}{l}\text { Village infrastructure } \\
\text { development }\end{array}$ & $\begin{array}{l}\text { Construction of concrete } \\
\text { Cast Roads and the } \\
\text { rehabilitation of Village } \\
\text { suspension bridges. } \\
\text { Most of the people just } \\
\text { know about the activity } \\
\text { when it will start } \\
\text { The infrastructure that has }\end{array}$ \\
\hline
\end{tabular}




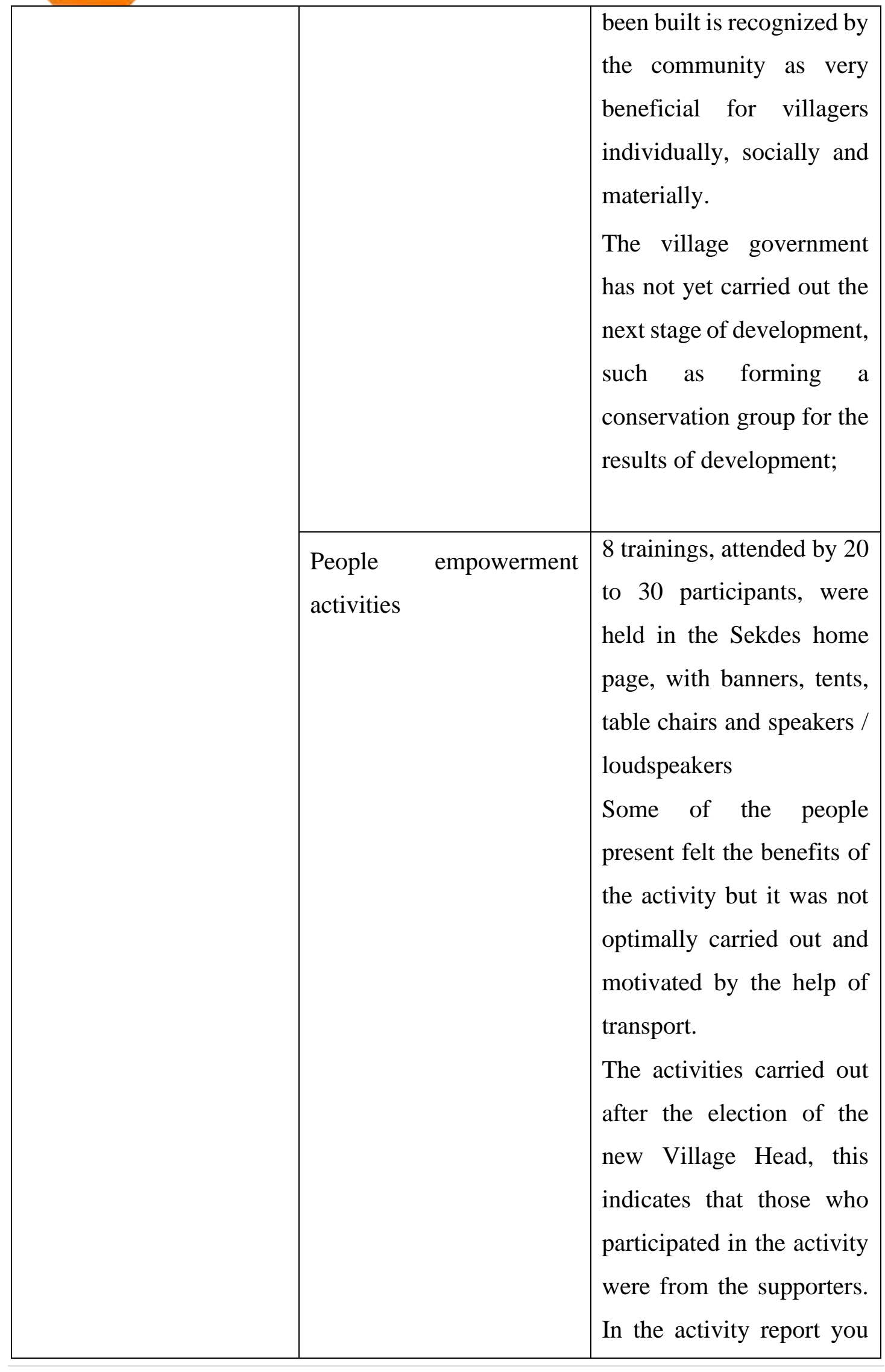




\begin{tabular}{|l|l|}
\hline & $\begin{array}{l}\text { can also see the attendance } \\
\text { list of participants, namely } \\
\text { the same number of people } \\
\text { who participated in some } \\
\text { training. } \\
\text { The expected benefits of } \\
\text { the training have not } \\
\text { opened up opportunities / } \\
\text { encouraged independence } \\
\text { for the community. } \\
\text { Management of the } \\
\text { BUMDes will be revised } \\
\text { and management training } \\
\text { will be needed so that the } \\
\text { BUMDes can run, as is } \\
\text { done in other villages as a } \\
\text { pilot project in Saling Sub- } \\
\text { District, Empat Lawang } \\
\text { District. }\end{array}$ \\
\hline
\end{tabular}

Community Participation in the Evaluation stage

Community participation in the evaluation phase includes monitoring the planning process, supervising service goods activities, making reports if irregularities are found and obtaining information on activities from the village government. Table 4 shows that community participation at the evaluation stage was not optimally involved.

Table 4. Community Participation in the Evaluation stage

\begin{tabular}{|l|l|l|}
\hline No. & Evaluation activities & Notes \\
\hline 1 & $\begin{array}{l}\text { Monitor and supervise the } \\
\text { planning process }\end{array}$ & $\begin{array}{l}\text { The community has not been involved } \\
\text { in monitoring and supervision }\end{array}$ \\
\hline
\end{tabular}




\begin{tabular}{|l|l|l|}
\hline 2 & $\begin{array}{l}\text { Monitor and supervise the } \\
\text { implementation of activities } \\
\text { (procurement of services, } \\
\text { administration, quality of the } \\
\text { results of activities) }\end{array}$ & $\begin{array}{l}\text { community participation only consists } \\
\text { of signing the administration because } \\
\text { they have received work wages and } \\
\text { transport fee }\end{array}$ \\
\hline 3 & $\begin{array}{l}\text { Make reports if there were odd } \\
\text { thing }\end{array}$ & $\begin{array}{l}\text { Get information or report on } \\
\text { activities from the village } \\
\text { government }\end{array}$ \\
\hline 4 & $\begin{array}{l}\text { Information in the form of a } \\
\text { development project board, overall } \\
\text { the Village Fund budget has not been } \\
\text { disclosed }\end{array}$ \\
\hline
\end{tabular}

In detail in table 5 the factors that support and hinder community participation in development programs with village funds are illustrated.

Table 5. Supporting and inhibiting factors of community participation

\begin{tabular}{|c|c|}
\hline Supporting factors & Inhibiting factors \\
\hline $\begin{array}{l}\text { Funding and regulatory support from the } \\
\text { government; } \\
\text { Open opportunities in the } \\
\text { implementation phase, } \\
\text { Equality of needs and a sense of family }\end{array}$ & $\begin{array}{l}\text { There is no Village Community } \\
\text { Empowerment Cadre in Kemang Manis } \\
\text { Village; } \\
\text { Limited knowledge of the village } \\
\text { apparatus } \\
\text { Socio-Political Atmosphere in the } \\
\text { Village }\end{array}$ \\
\hline
\end{tabular}

\section{Conclusion}

Based on the results of the community participation dimensions above, it can be concluded that the participation of the Kemang Manis village community in the Village Fund program in 2016 tends to be still low at the decision making stage, and the 


\section{OAIIJSS Open Access Indonesta}

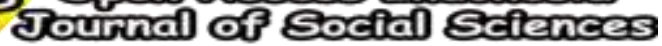

evaluation stage. However, for some stages of community participation went quite well, namely the stage of implementation of activities and the community felt and enjoyed the benefits of village infrastructure development. Therefore, it is still necessary to undertake a participatory approach to the elements of the community and the village government together with assistants, in order to increase community participation in the village development process. Village Development includes elements of the community from the planning stage to foster a sense of belonging to the program of activities, accommodating the values of local wisdom, perceptions, attitudes and behavior of the local community as well as the development objectives in accordance with the aspirations and answers to problems from the community.

Some factors that encourage community participation in the Kemang Manis Village are funding support and regulations from the government, opening opportunities for participation at the implementation stage as well as a feeling of the same needs and kinship in the community of Kemang Manis Village. Factors that hampered community participation in Kemang Manis were the absence of a Village Community Empowerment Cadre, limited knowledge of the village apparatus and the socio-political atmosphere in the Kemang Manis Village.

\section{References}

Akbar, R.J dan Prabatmodjo, Hastu., Manisfestasi Partisipasi Masyarakat Dalam Menanggapi Implementasi PNPM Mandiri Perkotaan (Studi Kasus : Kelurahan Cibeunying dan Desa Cimenyan, Kecamatan Cimenyan, Kabupaten Bandung), Jurnal Perencanaan Wilayah dan Kota SAPPK V3N1

Alfitri, 2011. Community Development Teori dan Aplikasi. Pustaka Pelajar.

Alhafid. M.D. dan Sunaryo. B., Faktor-faktor yang Mempengaruhi Partisipasi Masyarakat Dalam Pelaksanaan Konsolidasi Lahan di Kelurahan Kramas, Semarang, Jurnal Teknik PWK Volume 4 Nomor 42015

Anggaran Pendapatan dan Belanja Desa (APBDesa) Tahun 2016 Desa Kemang Manis Kecamatan Tebing Tinggi Kabupaten Empat Lawang 
Awa, N.E., 1989. Participation and Indigenous Knowledge In Rural Development, dalam Knowledge : Creation, Diffusion, Utilization, Vol.10 No.4, June 1989 304-316, Sage Publication, Ins.

Azfandi M. Y., Muluk M.R.K, danMakmur M., 2015. Pemberdayaan Masyarakat Mandiri Perdesaan di Kabupaten Brambang, Universitas Brawijaya Malang.

Azhar Fikri., Partisipasi Masyarakat Dalam Musyawarah Perencanaan Pembangunan (MUSRENBANG) di Kelurahan Pengirian Kecamatan Semampir Kota Surabaya., Jurnal Kebijakan dan Manajemen Publik Volume 3, Nomor 2, MeiAgustus 2015 ISSN 2303 - 341X

Bahrudin, Agus., Pola Hubungan Pemerintah Desa Dan Parlemen Desa Menuju Good Governance, Serat Acitya - Jurnal Ilmiah UNTAG Semarang ISSN : 2302-2752, Vol.4 No.3, 2015.

Buku Bantu Pengelolaan Pembangunan Desa Edisi Desember 2016, berdasarkan UU Desa. Kementerian Desa, PDT dan Transmigrasi.

Cohen, J.M., dan Uphoff, N.T., 1980. Participation's Place in Rural Development :Seeking Clarity Through Specificity, dalam World Development, Vol.8, pp.213235

Cohen, J.M., Participatory Planning and Kenya's National Food Policy Paper, Food Research Institute Studies, Vol. XIX, No.2 1984.

Cohen., J.M., dan Uphoff, N.T., Rural Development Participation : Concepts and Measures of Project Design, Implementation, and Evaluation, 1977, Ithaca N.Y. Cornell Univercity.

Connor, D. M., 1988. A New Ladder of Citizen Participation, dalam National Civic Review V.77 No.3 May-June 1988.

Creswell, J. W., 2016. Research Design Pendekatan Metode Kualitatif, Kuantitatif, dan Campuran. Pustaka Pelajar. 


\section{OAIIJSS Open Access Indonesta}

Darmawi, Edi. Partisipasi Masyarakat Dalam Pelaksanaan Program Nasional Pemberdayaan Masyarakat Mandiri Pedesaan (PNPM-MP) Di Desa Talang Leak I Kecamatan Bingin Kuning Kabupaten Lebong. Jurnal Penelitian Sosial Dan Politik. ISSN : 2252-5270, Januari - Maret 2014.

Data Empat Lawang, Tahun 2015, Kerjasama BPS dan Bappeda Kabupaten Empat Lawang

Data Empat Lawang, Tahun 2016, Kerjasama BPS dan Bappeda Kabupaten Empat Lawang

Firdaus dan Zamzam, F., 2010. Teori Perencanaan Suatu Pengantar. Tunas Gemilang Press.

Hadi, R. H., Effendi I. dan Hasanuddin T., 2013. Peranan Kader Pemberdayaan Masyarakat Desa (KPMD) dan Partisipasi Masyarakat Pada Program Nasional Pemberdayaan Masyarakat Mandiri Perdesaan (PNPM-MP) Di Kecamatan Wonosobo Kabupaten Tanggamus, JIIA, VOLUME 1 No. 1, JANUARI 2013, Universitas Lampung

Kecamatan Tebing Tinggi Dalam Angka, 2016. BPS Kabupaten Empat Lawang. Liliweri, Alo, Sosiologi \& Komunikasi Organisasi, Bumi Aksara, 2014.

Laksana, N.S., 2013. Bentuk-bentuk Partisipasi Masyarakat Desa Dalam Program Desa Siaga di Desa Bandung Kecamatan Playen Kabupaten Gunung Kidul Provinsi DIY. Jurnal Kebijakan dan Manajemen Publik Volume 1, Nomor 1, Januari 2013.

Laporan Hasil Kajian Pengelolaan Keuangan Desa : Alokasi Dana Desa dan Dana Desa, Deputi Bidang Pencegahan KPK. 2015

Laporan Realisasi Pelaksanaan Dana Desa Tahap I (60\%) Tahun Anggaran 2016 Desa Kemang Manis Kecamatan Tebing Tinggi Kabupaten Empat Lawang.

Laporan Realisasi Pelaksanaan Dana Desa Tahap II (40\%) Tahun Anggaran 2016 Desa Kemang Manis Kecamatan Tebing Tinggi Kabupaten Empat Lawang. 
Laurian, L., dan Shaw, M.M., 2008. Evaluation of Public Participation : The Practices of Certified Planners, dalam Journal of Planning Education and Research 28:293-309. DOI:10.1177/0739456X08326532.

Lenak, C. N., Rares, J.J., dan Tampi, G., 2015. Partisipasi Masyarakat Dalam Pengelolaan Alokasi Dana Desa di Desa Lemoh Timur Kecamatan Tombariri Timur Kabupaten Minahasa, dalam JAP No.31 Vol III 2015.

Mahdavinejad M. and Amini M., 2011. Public participation for sustainable urban planning In Case of Iran,” doi:10.1016/j.proeng.2011.11.2032, Fakultas Seni dan Arsitektur, Universitas Tarbiat Modares, Tehran, Iran.

Maipita, Indra., 2014. Mengukur Kemiskinan dan Distribusi Pendapatan. UPP STIM YKPN

Mardikanto, T., dan Soebiato, P., 2012. Pemberdayaan Masyarakat Dalam Perspektif Kebijakan Publik, Alfabeta.

Mau, J.A., Peran Komunikasi Pemerintah Terhadap Peningkatan Partsipasi Masyarakat Dalam Pembangunan Bersumber Anggaran Pembiayaan Negara, JISIP : Jurnal Ilmu Sosial dan Ilmu Politik ISSN 2442-6962, Vol.4, No.2 (2015).

Nugroho, R dan Wrihatnolo, R. R., 2011. Manajemen Perencanaan Pembangunan. Elex Media Komputindo.

Potensi Desa Tahun 2014. Kecamatan Tebing Tinggi Kabupaten Empat Lawang. BPS Rencana Pembangunan Jangka Menengah (RPJM) Desa Kemang Manis Tahun 2015

Putra. T. G., Peran Pemerintah Daerah dan Partisipasi Pelaku Usaha dalam Pengembangan UMKM Manik-Manik Kaca di Kabupaten Jombang., Jurnal Kebiajakan dan Manajemen Publik, Volume 3, Nomor 1, Januari-April 2015 ISSN $2303-341 \mathrm{X}$

Putro., B. D., Peran Elite Intelektual Dalam Dinamika Masyarakat Antara Harapan dan Kenyataan, Jurnal Humaniora Volume XII. No.2/2000 
Rencana Kerja Pemerintah Desa (RKP Des) Tahun 2015 Desa Kemang Manis Kecamatan Tebing Tinggi Kabupaten Empat Lawang

Sensus Pertanian 2013 Hasil Pencacahan Lengkap Kabupaten Empat Lawang., BPS Kabupaten Empat Lawang., Katalog BPS : 5106010.1611

Singarimbun, M. dan Effendi, S., 1982. Metode Penelitian Survai. Lembaga Penelitian, Pendidikan dan Penerangan Ekonomi dan Sosial (LP3ES).

Suaib. Hermanto., Suku Moi : Nilai-nilai kearifan Lokal dan Modal Sosial Dalam Pemberdayaan Masyarakat, An1mage.

Sulistiawati, 2013. Partisipasi Masyarakat Dalam Pelaksanaan PNPM MP dan Efektifitassnya Terhadap Ketahanan Ekonomi Keluarga (Study di Kecamatan Kalanganyar, Kabupaten Lebak, Banten).

Tika, F.Y.A., Hanafi I., dan Riyanto. Implementasi Kebijakan Pemberdayaan Masyarakat (Studi Pada Pelaksanaan Program Nasional Pemberdayaan Masyarakat (PNPM) Mandiri Perkotaan di Kecamatan Batu Kota Batu). Jurnal Administrasi Publik (JAP), Vol 1, No.2, hal. 188-196

Usman, Sunyoto, 2012. Pembangunan dan Pemberdayaan Masyarakat. Pustaka Pelajar. Vredenbregt, J., 1978. Metode dan Teknik Penelitian Masyarakat. PT. Gramedia Jakarta. Wahjono, S.I., 2010, Perilaku Organisasi, Graha Ilmu

Wibowo, Rudi, 2011. Pendekatan Partisipatif Masyarakat Terhadap Implementasi Kebijakan Program Nasional Pemberdayaan Masyarakat (PNPM) Mandiri”, UPN Veteran Yogyakarta.

Wilcox, D., 2003. The Guide To Effective Participation. The Joseph Rowntree Foundation dan partnership.org.uk., ISBN 1-870298-00-4 
